\title{
Control and Usage of the Virtual Space in Facing the Upcoming 13th General Election - A Critical Evaluation of Space and Opportunities for Barisan Nasional
}

\author{
Badrul Azmier Mohamed \\ Faculty of Administrative Science \& Policy Studies \\ Universiti Teknologi MARA, Kedah, 08400 Merbok, Kedah, Malaysia \\ Tel: 60-4-456-2485 E-mail: badmohamed@kedah.uitm.edu.my \\ Mujibu Abd Muis \\ Faculty of Administrative Science \& Policy Studies \\ Universiti Teknologi MARA, Kedah, 08400 Merbok, Kedah, Malaysia \\ Tel: 60-4-456-2483Ｅ-mail: mujibu@kedah.uitm.edu.my \\ Azni Syafena Andin Salamat \\ Faculty of Administrative Science \& Policy Studies \\ Universiti Teknologi MARA Kedah, 08400 Merbok, Kedah, Malaysia \\ Tel: 60-4-456-2513 E-mail: azni_syafena@kedah.uitm.edu.my
}

Nur Zafifa Kamarunzaman

Faculty of Administrative Science \& Policy Studies

Universiti Teknologi MARA, Kedah, 08400 Merbok, Kedah, Malaysia

Tel: 60-4-456-2388 E-mail: nurzafifa@kedah.uitm.edu.my

Syazliyati Ibrahim

Academy of Language Studies

Universiti Teknologi MARA Kedah, 08400 Merbok, Kedah, Malaysia

Tel: 60-4-456-2512Ｅ-mail: syazliyati@kedah.uitm.edu.my

Robekhah Harun

Academy of Language Studies

Universiti Teknologi MARA Kedah, 08400 Merbok, Kedah, Malaysia

E-mail: robekhah@kedah.uitm.edu.my

Zetty Harisha Harun

Academy of Language Studies

Universiti Teknologi MARA Kedah, 08400 Merbok, Kedah, Malaysia

E-mail: harisha@kedah.uitm.edu.my

Received: May 25, 2011

doi:10.5539/ass.v7n12p14
Accepted: June 30, 2011

Published: December 1, 2011

URL: http://dx.doi.org/10.5539/ass.v7n12p14 


\begin{abstract}
The significant roles of the virtual space is undeniable in today's society. Despite its intangible nature, its impact is being seen in most of the domains in human's life in the real world. Even in the political sphere, a myriad of events and phenomena which happen could be the effects of what transpire in the virtualspace. It is found that in spite of various actions taken by the authority to curtail its influence, the anarchic elements and ultimate freedom enjoyed in the virtual world still prevail. This leads to anxiety in the ruling party which political survival has always depended on its success in controlling the practices in the government's administration. Such control is deemed necessary to prevent and demolish any forms of subversion. Ironically, this concept of control is now regarded as an outdated framework. Due to such control too, most plans for further changes or reformations will be difficult without some forms of assistance from the virtual space. As a consequence, the government of the day whose power is already established also feels compelled to extend its influence to the virtual world so that the virtual community can be persuaded to lend their support to the existing government. Recently, numerous political events which clamour for more democratic changes are taking place locally as well as internationally. Such uprisings indirectly raise some questions regarding Barisan Nasional as a ruling party which survival has been ascertained by the "controlling machine". Hence, this article attempts to review the ruling party's usage and harrassment of the virtual space at the federal level in its endeavour to maintain its hegemony as the only ruling party in the coming 13th General Election. This study utilised content analysis and observation towards any statements, actions or policies promoted by any political actor related to the ruling party in the usage and harrassment of the virtual space in Malaysia.
\end{abstract}

Keywords: Malaysian politics, Virtual world, Internet, Facebook, Blog, Democracy

\title{
1. Introduction and Background of Study
}

Half a century has passed and Barisan Nasional is still there. In other countries, different parties have taken their turns to rule. In many countries in the world, the current ruling parties have had the experience of becoming the opposition parties before. However, such an experience has never been felt by Barisan Nasional which continues to enjoy its hegemony in Malaysia. Recently, the political climate in various countries has been influenced by the advancement in ICT. A few old regimes were ousted due to the mobilisation caused by the political movements in the virtual world. As posited by Huntington, now is the time for 'the Fourth Wave of Democratisation' which occurs after 20 years of 'the Third Wave of Democratisation'. Tunisia, Mesir, Libya, Algeria, Jordan, Yemen and Bahrain all witnessed the impact and success of the virtual world which spilled into real events in the real world. Hence, the sturdy appearance of Hosni Mubarak is now a part of history. What was once unthinkable, like the Libyans rising with their weapons and were willing to die rather than accept Muammar Ghaddafi as their leader, actually took place and truly shook the world. Do all these have any relevance to Malaysia? Najib Razak as the chairperson of Barisan Nasional purported that Malaysia is different from those Arab countries. At a glance, the words ring true beacuse Barsian Nasional has time and again proven that it is a staunch political entity. East Asia democratisation as a result of the Asian Economic Crisis in 1997 saw the collapse of the military regime in South Korea, Kuomintang in Taiwan and Golkar in Indonesia. But Malaysia survived this triumphantly. Some tremors in the political sphere was only felt during the 12th General Election on 8 March 2008, when Barisan Nasional was denied its two-third majority votes which had always been its benchmark. The popular belief was that this unexpected event happened due to the roles of blogs in the virtual world. Hence, if now Egypt celebrates a Google executive as a hero, Malaysia has long felt the effects of the virtual community's actvities back in 2008. The main difference was that the virtual space in Egypt helped to mobilise a revolution whereby in Malaysia, it served as a wake up call. The 'Jasmin Revolution' in Tunisia and Egypt highlighted the failure of the ruling regime to handle the changes requested by the poeple. Therefore, this article aims to evaluate the activities in the virtual space which emphasise Barisan Nasional's control and usage of the new realm and to seek an understanding of whether these activities are effective to create oppportunities and space for the ruling party in the coming 13th General Election.

\section{The Virtual Space and Politics}

Past research has accentuated the close relationship between the virtual world with politics and stressed the need of its control and usage in order to ensure the longevity of the ruling party. Faris Shirazi (2010) shared his experience on how the ruler of Iran used the excuse of ' the internal security' to validate the government's tight control over the virtual world. This control was enforced after the 'green revolution'. This revolution grew since the Iranians believed that there was a hoax during the presidential election in June 2009. The claim that Mahmoud Ahmadinejad was re-elected with 63 percent of votes throughout the country saw the people flooding the streets as a show of protest. Thousands of pictures and video clips were uploaded into the social networking websites like Facebook, Twitter as well as YouTube during the time. It attracted the attention not only in Iran but also the world. 
Like most countries laden with autocratic elements, the rule of Iran prohibited the conventional media like the newspaper, radio and television from airing or reporting the events. In doing so, the people were forced to resort to the virtual world in order to document and disseminate the information related to the events. The people were mobilised into the streets by the communication amongst the young people through the social networking websites.

Tan (2020) also shared his experience regarding the virtual space in Malaysia when the reformation movement was still very new. According to him, the relationship between the virtual space and politics in Malaysia was stengthened soon after the dismissal of Anwar Ibrahim. This pivotal point in Malaysian politics coincided with the rapid technological advancements in ICT in the country. As a consequence, the virtual world started to become a vehicle for political mobilisation due to very limited political space in the real world. Limited space in the world has also resulted in the virtual space becoming the medium of choice by the opposition's sympathisers.

Fischer (2009) in his study on the history and ethnography of the upper middle class suburban Malays from 2001-2002, found that quite a big number of users in the virtual world who volunteered or sought political information in the new realm had high political awareness. This group of people also tend to support the opposition or neutral. There were some supporters of the ruling party but the number was small. The most noticable fact was that these people frequent the virtual world in order to obtain information which could not be uncovered in the real world.

The freedom of speech in the real world as purported by Mohd Azizudin (2010) suggested that Malaysia had never actually practised the freedom of speech as enjoyed by the western countries such as Britain or the United States of America. Our concept of free speech was first established by the British, who paradoxically, was also responsible in introducing the law which limited our freedom of speech. Furthermore, in order to enhance the mechanism in the judicial system, the ruling party introduced the Internal Security Act in 1960, Official Secret Act (1972), Sedition Act (1948), Printing and Print Machine Act (1984) and University and Unversity College Act (1971). According to Mohd. Azizudin (2010), no matter what the reason is, abiding by the law as stated in the judicial system will have direct positive impact on the ruling party. Hence, it is obvious that the situation in the real world in Malaysia is well controlled and the freedom of speech is well contained.

A research by Krueger (2005) in the USA uncovered the relationship between the ruling party's control over the virtual world with the people's political participation in the virtual space. The findings indicated how the usage of the virtual world could be controlled by the ruler through efficient judicial system and sophisticated deployment of ICT. Wright (2009) also identified how a political party might manipulate the space and opportunities provided by the interactive features in the virtual world to its advantage. Focusing on blogs, he found that the writings of politicians were not so popular possibly due their failure in utilising the interactive features in the blogs. Certain politicians even decline any comments from the readers. This resulted in possible two-way communication being reduced to one-way communication. Due to this, the politicians were seen as failing in functioning as the voice for the people.

Serfaty (2010) on the contrary found that winning an election had a relationship with a candidate's level of popularity in the virtual space. The number of friends in one's account be it Facebook, MySpace, Friendster, and Ning, might influence a candidate's winning probability. He studied the campaigns conducted for the USA and French presidential elections. It was noticed that the candidates and the voters did not have many opportunities to meet one another physically or personally. However, in the virtual space, the social networking websites provide the ground and chances for both parties to interact, communicate and construct their own perceptions with more personal touch.

Recent research and articles obviously reported that the roles of the virtual world in politics are becoming increasingly important. Hence, any political parties, particularly the one still in power, should never take this issue for granted. A ruling party which has been in power for quite some time and is known with autocracy should be more cautious. The controlled climate in the conventional media in the real world may provoke the people to choose the virtual world when they want to obtain, disseminate and share any information amongst them. The proliferation of social networking websites only increases the interactive nature of this new realm. Therefore, the virtual space has truly overcome the conventional media in various different respects.

\section{Malaysian Politics in the Real Space}

There are certain limitations of political opportunites in Malaysian politics. The terms used by scholars to define the level of democracy in Malaysia are also used to explain political opportunities in the real world. Zakaria labelled Malaysia as 'quasi-democracy', Case defined it as 'semi-democracy', Crouch interpreted it as 'neither authoritarian nor democracy' whereas Jesudason gave the term 'statist-democracy'(Jamaie et. al, 2005). Other 
than that, Malaysian democracy is also interpreted as 'authoritarian populism' by Munro-Kuo and 'coercive consociationalism' by Mauzy (Wan Abul Rahman Wan Abdul Latif, 2002). All the terms were mostly centered on the democracy record of the ruling party during Mahathir Mohamad's administration.

Before taking over the Prime Minister post on 3 April 2009, majority expected Najib Razak's administration to follow the footsteps of Mahathir Mohamad and continued the previous Prime Ministers' practices. This would be true if seen from the prespective of Freedom House Press Freedom Index of 2010 which categorized Malaysia as a 'not free' country along with Vietnam, Cambodia, Laos and Myanmar for media freedom category (Freedom House Press Freedom, n.d). As for the score of political opportunities and freedom, Malaysia scored 4, which qualified it for the status of 'partly free'(Freedom House Press Freedom, n.d).

This situation was expounded by Tan (2010) who explained about the political opportunities in the real space of Malaysian politics. In the real space, political opportunites are limited, those who expressed their feelings on the roadsides will be greeted with batons; tear gas; water canons; prison and the court. In addition, all the 'political advice' are clearly daunting. The maintream medias, whether the newspapers, televisions or radios are not the media for the public but rather act as part of one-way communication apparatus for the ruling party. As for the existence of the alternative newspapers and magazines; circulation is 'for members only'; the permits are not renewed/ withdrawn and publications are also limited. The justification that wasgiven for all the limitations is 'for national security' as what had happened in Iran during the 'green revolution' (Farid Shirazi, 2010). Thus, according to Tan (2010) this situation has created quite a critical political discontent. Therefore, it is partly the reason why the virtual space has become a dynamic column for politics.

\subsection{Control of the virtual space in malaysian politics}

Discussion about virtual space in Malaysian politics started along with the emergence of reform movements. The reform movements emerged as a result of a few shocking political incidents which were Anwar Ibrahim's dismissal from all administrative and party posts along with the prosecution of sexual misconduct that had caused controversy locally and abroad. Due to the limited opportunities in the real space, the reformists chose to manipulate the real space of anarchy.

The political rivals tried to manipulate the situations in the Middle East lately by comparing Malaysian politics and economy which they allegedly accused has much in common. This, has evoked the concerns of Barisan Nasional. Thus, Rais Yatim the Minister of Information, Communication and Culture as the government representative claimed that current law provisions can be used although the 'provocative' statements were located in the virtual space. ("Tindakan keras jika hasut rakyat guling kerajaan", 2011). According to Rais Yatim, the Communication and Multimedia Commission, Royal Malaysia Police and related agencies will monitor the social networks such as Facebook, short massaging system and the other alternative medias ("Tindakan keras jika hasut rakyat guling kerajaan", 2011). In the same note, the Minister of Internal Affairs, Hishammudin Hussein said the government can act in accordance with the provision of the Internal Security Act ("Tindakan keras jika hasut rakyat guling kerajaan", 2011).

Earlier, at the National Hall conference on 3 August 2010, Rais informed that all types of network contents including those in the virtual sites are subjected to four acts; Sedition Act 1948; Penal Code; Internal Security Act 1960; and Communication and Multimedia Act 1998 ("Empat akta kawal maklumat berangkai dalam laman web", 2011).

The Government can enforce various acts to control the freedom of the virtual space. However, according to Tan (2011) who studied the development of the virtual space since the emergence of the reform movements, there were less enforcement of legal provisions used to control the virtual space.

The seizure of Malaysiakini computer; Jeff Ooi's screenshots case; April Fool issue; the spreading rumors of chaos in the city issue; Brandmalaysia blog issue; 'provocative web' issue, harrasments from the opposition websites, and the issue between EMC Libra and Harakahdaily.com were among the cases discussed by Tan (2011). Other than that, there were also efforts made between the Ministry of Information and bloggers in May and June 2008 (Muhamad Nadzri Mohamed Noor \& Suhaimee Saahar@Saabar, 2008). The Ministry had also assigned several officers for monitoring purposes. Meanwhile, the peak of the government interference towards the virtual space was when Raja Petra Kamarudin was detained under the Internal Security Act on 12 September 2008. A week after his detention, the owner of 'Kickdefella' blog, Syed Azizi Aziz was also detained under the same act.

Approaching the 13th General Election, Najib Razak's administration was seen as trying 'quite hard' in controlling the virtual space. There are two cases that attracted the public; first, the case of Amizudin Ahmad the owner of sharpshooterblogger.blogspot.com; second, Muhammad Nur Hanief Abdul Jalil's (Hanief) case. In the first case, 
the Kuala Lumpur High Court on 2 February 2011 has granted the injuction to Rais Yatim to prevent a blogger, Amizudin Ahmad (Din Binjai) from publishing the issue related to the disclosure of the Minister of Information. Amizudin Ahmad redisplayed the wikileaks exposure that he took from Rockybru blog owned by Ahirudin Atan. It is interesting to note that Ahirudin Atan who is a supporter of the ruling party was not liable for any actions.

Meanwhile, on 18 Mac 2011, another blogger, Muhammad Nur Hanief Abdul Jalil (Hanief) was arrested by the police and Communication and Multimedia Commission of Malaysia without a warrant. He claimed a few of his father's computers, laptop and modem were seized ("Tahan blogger tanpa waran, tindakan umpama negara polis" 2011).

From the list of incidents mentioned it clearly shows that they were trying to avoid the empowerment of Acts. Although the Internal Security Acts were used, immediate release was done. Therefore, the action of controlling the virtual space is prone towards warnings, threat to use the available acts, 'interviews' by the police, search warrants up to hardware confiscation. This, also portrays the control of virtual space by the govenment is more in the form of 'harrassment' than empowerment. The types of harrassment can be divided into two forms; harrassment in the real space; and ; harrassment in the virtual space. The real space harrassment has been described above. Meanwhile, physical harrassment like confiscating hardware such as computer sets can paralyse any movements in the virtual space (Tan Lee Ooi, 2011, pg. 135)

On the other hand, the virtual space harrassment is done by a group of people known as the 'cybertroopers' and their existence in the virtual world is questionable as nobody knows whether they are paid or not. These people argue well, appear to be educated, have good language skills in both Bahasa Melayu and English, and can rationally defend the ruling party from all angles. In addition, they are able to effectively attack the opposition parties. The virtual space harrassment could also be done technically. This is mentioned by Tan (2010) as cyber attack. Nevertheless, there were no official records of cyber attacks by the government on any websites. However, these technical attacks are experienced by many and have paralysed websites which are pro the oppositions such as Anwar Online, Black 14 and Malaysia Today. It could easily point to the ruling party if we analysed the dates when the websites were hacked during the political environment at that time.

\subsubsection{Between enforcerment and harassment}

The dilemma of 'enforcement versus harrassment' could be explained from the economic point of view. As a developing country (Sity Daud, 2004), every action should not affect the development. The practice of a developing country started in Mahathir Mohamad's era and further extended to Najib Razak's era. Although Najib Razak's administration highlights liberalisation policy, it is found that the government still plays a big role in the economy. In fact, the government participation in Malaysian economy still continues through various ways in numerous sectors and industries.

Multimedia Super Corridor, Mahathir Mohamad's legacy is one example of the role of the government in the developing information technology. Inevitably, information technology must be developed for Malaysia to be ready to face the challenges of globalization. However, the rapid development in information technology has brought large impact side effects. It has created a new public space for the people since 1998 which are profiting the oppositions rather than the government. This is to ensure the development of the information technology sector, thus, foreign direct investment in this sector should continue their presence in Malaysia. The multi-national companies believe that interference or control by the government could affect its development. Therefore, at the beginning of the launching of the Multimedia Super Corridor, foreign investors who were operating in Malaysia had guaranteed that the contents of the websites in our virtual space were free from any control. According to Tan (2010) the assurance given by the government was like the First Amendment of United States Constitutions.

The launch of the New Economic Model by Najib Razak with the notion to prepare Malaysia for the global competition has caused Malaysia to be unable to avoid providing conducive space to the development of information and communications technology sector. It coincides with the intention to transform Malaysia from an industrial-based economy / production / manufacturing / export base, to a service-based economy / knowledge / human capital that are loaded with innovative elements. So, this is why the choice of interference has been chosen in comparison to law enforcement. Environment close to anarchy in the virtual space continues in Malaysia for the factors of development despite the ruling party facing a number of claip. Nevertheless, any control measures that are turned towards the empowering the economy do give an impact on the political stability which causes negative impact on the ruling party itself. 


\subsubsection{The use of virtual space by ruling party}

Barisan Nasional is aware of the importance of virtual space, especially social networking sites. It is in line with a research by Wright (2009) who identified political parties; whether government or non-government can use the space and opportunity of the interactive features of the virtual space. The improved performance of rival party alliances in General Election, 12 was said to be because of the use of virtual space which has then taken an imminent role in Malaysia's political influence. In particular, the blog and blogger was found to be a medium and an important political actor in the development of political landscape of the era of a political tsunami in March 2008. The defeat at the ballot box with urban youth voters could be used as the empirical evidence. It is due to the fact that the virtual space is occupied by the population of young, middle class, educated, critical, and urban.

Now, in a series of elections which took place after March 2008, the ruling party began to reach out to voters by using websites such as Facebook. For example, a candidate for the Legislative Assembly N.27 Merlimau, Malacca used Facebook in order to reach the community ("Roslan uses Facebook to pull up young voters", 2011). He used the site to answer all the questions that people raised in the Legislative Assembly Merlimau. For him, it was helpful, especially regarding his interactions with young people. While in the election for State Assembly Kerdau N.28, Pahang Barisan Nasional election machinery used social sites like Facebook and Twitter to connect with 3.680 young voters who were staying or studying overseas ("Facebook traces young voters", 2011). Serfaty (2010) found that victory in an election can be influenced by the popularity of the candidates in a virtual space and it has become a reality in the election of Kerdau and Merlimau.

Najib Razak, chairman of the Barisan Nasional, Umno president, who is also Prime Minister of Malaysia is among the politicians of the ruling party who maximizes the use of virtual space. He has two accounts in Facebook and Twitter and it is increasing in their popularity. Najib Razak also ensures that his virtual friends become real by organising a tea ceremony thus ensuring he could meet up with his Facebook friends. Recently, he organized a session of "Mari Berjumpa Mari Berhubung" with his virtual friends up in Kuching, Sarawak on March 19, 2011. In addition, the proliferation of information technology continues to be used when the Chinese New Year greeting is sent via short messaging service to 4 million people in Malaysia and emails were sent to $1,255,528$ people ("Najib does not violate the privacy of telecommunication company", 2011). The ruling party was also identified as using the virtual space to highlight the community service they offered. For example, over 33,000 have registered online at www.bnyouthjobfair.com.

Recently, through the TNS Global Market Research study found that the people of Malaysia are the most popular Facebook users in the world (Malaysians most popular, most frequent users of social network, 2010). In fact, the people of Malaysia are also the most frequent users of social sites. Thus, the virtual space creates opportunities for the ruling party to reach out, serve, and then accompany the young and educated with ease.

Instead of giving harm to Barisan Nasional, the virtual space can be beneficial when applied to the maximum extent possible. The presence of virtual space browsers that host the ruling party supporters, known as "cybertroopers" provides an opportunity for the ruling party to fend off attacks and respond to political attacks on rival parties. However, the approach of cybertroopers may have to be reassessed. This is because the description of the image brought by the cybertroopers is not the same with the image put forward by the leaders of the ruling party at the national level. Moreover, it is the belief that their presence in the virtual space is paid, not voluntary.

Approaches like racism, personal attacks, character assassination, provocation and intimidation that use widely gross terms was found both in blogs and social sites like Facebook and Twitter. To distinguish the ruling culture of competitors who are often accused by the ruling party to use political strategies that have been mentioned earlier, these approaches may not be necessary. It is also not in line with the concept of "1 Malaysia, Rakyat Didahulukan, Pencapaian Diutamakan "and the transformation efforts by the ruling party. Similarly, the provoking or harassing the sites maintained by the oppositions do not cause the opposition symphatisers to be attracted to the ruling party. Thus, the approach of explaining and clarifying was more effective.

\subsubsection{The existence and visits}

The dilemma of the ruling party in the virtual space is the presence in the virtual space does not get visits from the target group of people who do not support or vote Barisan Nasional. Although the supporters are also part of the target groups, their needs for the alternative information are minimal. This is because their needs can be met by the mainstream media. On the contrary, the independent and critical supporters of the opposition, or apathetic citizens visited the virtual space to get alternative information. It is consistent with the ethnographic study of Fischer (2009) who have identified that most of the information contributors who choose to receive political information in virtual space has a high political awareness. Thus, the existence of the virtual space by the informant was to get different information than what is served by the mainstream media following the disclosure of the virtual space itself 
(Fischer, 2009). Hence, it explains why the searches concerning the ruling party-related are more towards the satirical, gossip, exaggeration, and the scandal than informative.

This explains that some of the Malaysians wish the information to be impartial, balanced, and different from what is offered by the mainstream media in the real space. Furthermore, the characteristics of the virtual space have become more interactive due to the emergence of social sites like Facebook and Twitter. Here they not only receive information, but they can and are even allowed to express themselves and share their grievances. Not only that, the emergence of sites like YouTube which provides access to audio-visual applications, offers an alternative to television. It allows any coverage that has been 'black out' to be watched by the public. Thus, the virtual space is available to complete the requirements and of the real space. As described by Mohamed Noor Mohammad Nadzri \& Suhaimee Saahar@Saabar (2008) that identifies the method of purposive depoliticization that has long practiced by the ruling party to minimize politicking has inhibited some of the basic pillars of democracy, Malaysia, in particular the mass media. According to Mohamed Noor Mohammad Nadzri \& Suhaimee Saahar@ Saabar (2008) the practice is causing major media in Malaysia to be unable to exercise his functions as a media society, but has become the ruling party media. Thus, the experience felt in the websites and media of the ruling party in the virtual space is actually the implication of constraints of the political opportunities in the real world.

\section{Conclusion}

The $13^{\text {th }}$ General Election is very important for the ruling party. It is more important for the Chairman of Barisan Nasional, Najib Razak, as it is the 'real' mandate of to him. This is because the Barisan Nasional wins a majority in 2008 to Abdullah Badawi. Hence, the victory, the majority of the votes, it's important to determine the extent of the mandate of the people, not only to Najib Razak, or National Front, but also as a signal acceptance or rejection of the transformation agenda and use the concept of "1 Malaysia Rakyat Didahulukan Pencapaian Diutamakan, The New Economic Model and Government Transformation Program. Meanwhile, in the era of Twitter and Facebook as well, all these variables are an indication of the continuity of the ruling coalition Barisan Nasional in Malaysia.

Thus, control and management of virtual space by the Barisan Nasional is vital. A wrong step in the virtual space can bring bad luck, like what happened to the autocratic old regimes in Egypt and Tunisia. Thus, any attempt to law enforcement on cyber space is not a wise step. First, it eroded the confidence of foreign investors which could affect the national economy. Second, socio-political climate must be compatible with the New Economic Model. Review aspire to high-income laden with incentives to innovate, it is a democratic climate. Thirdly,"gendang gendut tali kecapi, kenyang perut suka hati". This is a representation of the people of Malaysia (and other Asian societies), which did not bother about democracy (Badrul Azmier Mohamed @ Bakar, 2008). It is about survival, adequate food and adequate use. But the big dilemma appears when searching the history, the reality of democracy is the medication (stagflation in) economics (Badrul Azmier Mohamed @ Bakar, 2008). Today's environment seems to signal to democratization. However, the public and the government is still thinking, acting, and being emotional in the horizontal framework of communal politics, which the democratization of the alleged, feared could bring anarchy.

Therefore, the management and operation of virtual space, the concept of 'order and nuisance' can still continue to be practised in Malaysia. With 15 years of virtual space sites in Malaysia, it seems that it has become the best practice. If before 2008, the ruling party was more focused on 'nuisance', so by the General Elections-13 the focus on the 'order' is expected to bring benefits. This is more relevant as the party itself is responsible for providing a virtual space infrastructure in Malaysia. Now, there is an alternative space which can be seen as an opportunity than a threat.

\section{References}

Badrul Azmier Mohamed@Bakar. (2008). Lima puluh satu tahun dominasi Barisan Nasional dalam politik Malaysia: Suatu analisis. In Worran Hj Kabul, Shireen Haron, Mat Zin Mat Kib, Abdul Kadir Rosline (Eds.), Seminar Politik Malaysia: Lanskap Politik Malaysia Pasca Pilihanraya ke-12 (pp. 789-802). Shah Alam: Pusat Penerbitan Universiti.

Empat akta kawal maklumat berangkai dalam laman web. (2011, Mac 8). Utusan Malaysia.

Facebook jejak pengundi muda. (2011, Mac 4). Berita Harian, p. 6.

Farid Shirazi. (2010). The emancipatory role of information and communication technology: A case study of internet content filtering within Iran. Journal of Information, Communication \& Ethics in Society, 8(1), 57-84.

Fischer, J. (2009). 'We shift the channel when Mahathir appears': The political Internet and censorship in Malaysia. Akademika: Jurnal Sains Kemasyarakatan dan Kemanusiaan, Januari-April, 43-64. 
Freedom House Press Freedom Index 2010 (n.d.). Dari. [Online] Available: http://www.freedomhouse.org

Jamaie Hamil, Mohd. Mahadee Ismail, Nidzam Sulaiman \& Suzanna Mohamed Isa dan Zaini Othman. (2005). Budaya politik Melayu: kesinambungan dan perubahan. In Sity Daud \& Zarina Othman (Eds.). Politik dan Keselamatan (pp. 71-98). Bangi: Penerbit Universiti Kebangsaan Malaysia.

Krueger, Brian S. G. (2005). Government surveillance and political participation on the Internet. Social Science Computer Review, 23(4), 439-452. http://dx.doi.org/10.1177/0894439305278871

Malaysians most popular, most frequent social network users. (2010). Dari. [Online] Available: http://www.redorbit.com/news/technology/1941050/malaysians_most_popular_most_frequent_social_network_ users/index.html

Mohd Azizudin Mohd Sani. (2010). Freedom of political speech and social responsibility in Malaysia. Bangi: Penerbit Universiti Kebangsaan Malaysia.

Muhamad Nadzri Mohamed Noor dan Suhaimee Saahar@Saabar. (2008). Blogosphere: Ruang kontra hegemoni? Analisis terhadap blog politik Malaysia terpilih dalam PRU 2008. In Worran Hj Kabul, Shireen Haron, Mat Zin Mat Kib, Abdul Kadir Rosline (Eds.), Seminar Politik Malaysia: Lanskap Politik Malaysia Pasca Pilihan Raya Ke-12 (pp. 59-68). Shah Alam: Pusat Penerbitan Universiti.

Najib tak langgar privasi syarikat telekomunikasi. (2011, Mac 9). Berita Harian, p. 12.

Roslan guna Facebook tarik pengundi muda. (2011, Mac 3). Berita Harian, p. 8.

Serfaty, V. (2010). Web campaigns: Popular culture and politics in the U.S. and French presidential elections. Culture, Language and Representation, 3, 115-129.

Sity Daud. (2004). Globalisasi dan negara pembangunan. Akademika: Jurnal Sains Kemasyarakatan dan Kemanusiaan, Januari: 27-42.

Tahan blogger tanpa waran, tindakan umpama negara polis. (2011). Dari. [Online] Available: http://www.keadilandaily.com

Tan Lee Ooi. (2010). Dinamik ruang siber dalam gerakan reformasi di Malaysia. Bangi: Penerbit Universiti Kebangsaan Malaysia.

Tindakan keras jika hasut rakyat guling kerajaan. (2011, Mac 6). Berita Harian, p. 2.

Wan Abdul Rahman Wan Abdul Latif. (2002). Antara persaingan dan perwakilan. In Ghazali Mayudin (ed.), Politik Malaysia: perspektif teori dan praktik (pp. 1-25). Bangi: Penerbit Universiti Kebangsaan Malaysia.

Wright, Scott. (2009). Political blogs, representation and the public sphere. Aslib Proceedings: New Information Perspectives, 61(2): 155-169. 